elevating the nutrition, improving the general condition, and regenerating tbe blood and bodily fluids. If this view he correct, any procedure wbicb causes destruction of the surronnding capsule, witb setting free of the hacilli, carries with it the danger of dissemination. This is illustrated in tbe general io fection following operntive treatment of tubereulous bone disease and of fistula-in-ano of tuberculous character.

\title{
SURGRRY.
}

\section{UNDER THE CHARGE OF}

J. WILLIANT WHITE, M.D.,

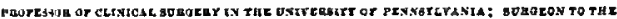

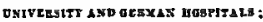

As\$isten $\mathrm{kT}$

Edward Martin, M.D.,

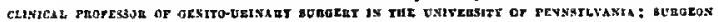

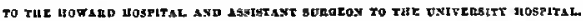

\section{The Supposed Corative Effect of Operatioss, per se,}

Under this title, Dr. J. Willcasr White, of Philadelphia, eontributes a paper to the Annals of Surgery for Augast, 1891, which, not only from its subject, hut from the great number of authorities quoted and from the peculiarly ricl cxpericnce of the writer, malses an artiele of unusual interest and importance to hotb surgeon and plysiein. The autbor's attention was first directed to this subject by reason of his experience with the operation of trephining for so-called traumatic epilepsy.

During the past fire years, witb Dr. D. Hayes Agner, he has treplincd in fiftecn cases of supposed traumatic epilepsy. All but one recovered from the operation. Tbc patient who perished was an imbecile and a confirmed drunkard, as well as an epilcptie. Death occurrcd from suppression of urine, probably secondary to etbcrization.

In one case $\Omega$ bullet was found jmbedded in the brain substance; in another an irregular portion of the internal tahle was dissceted out from beneath the dura mater, to whiels it was attaehed by cicatricial adhesions. In another there were projecting spicules of bone on the internal surface of the button remored and the adjaecnt portions of the skull. In $t \pi 0$, marked sclerosis and thiekeniog of the eranium sere obserred about the field of operation. In the remaioing cases nothing abnormal was seen. Although this was the ease, they were, witbout exception, markedly improsed by treplining, in two instanees even to the point of apparent eure, no return of symptoms having been obserred for eiglitcen months and for two years after the operation. In the other seren the results mere strikingly farorable, conrulsions disappearing for weeks or months, although previously of more than daily oecurrence. 
The autbor bas, in so far as this is possible, classified the cases in which operation per se seemed to he the main pactor in bringing ahout a cure. These cases are divided in to three groups, in accordance with the anatomical sent of the symptoms or of the supposed disease. This brings them under the following heads:

1. Operations for the relief of nerrous phenomena, as epilepsy, insanity, paralysis, etc.

2. Operations for abdominal and pelric disorders, as peritonitis, tumors, ete.

3. Miscellaneous operations.

This classifieation is further carried out hy groupiog together $(a)$ those enses. in wbich nothing whatever was found explanatory of the symptoms; $(b)$ those in whicb some departure from normal eonditions was observed, but was so slight as to be appareatly insdequate to explain the symptoms; (c) those crses in which an apparently grave and irremediable condition wns disclosed hy an exploratory operation, but notably improved or nltogether disappeared after mere inspection and handling, no further surgical interference having heen thought justifiable.

Under the heading of "Operatinns for the Relief of Nerrous Plenomena," Dr. White has tabulated, inclading his own service, $15 t$ cases. Many of these are given in detail, and coning as they do from recognized authorities, are of exceeding great interest.

In 56 cases of trephining for epilepsy nothing ahnormal wis found to account for the symptoms. Nineteen cases were reported in sis months or less after operation; 11 cases were reported from one to two years after operation; 1 was reported eight years nfter operation.

Of these cases 25 were reported as cured; 18 as improved; in 3 it was mentioned that a relapse oceurred later.

In 30 cases of ligation of bloodressels for epilepsy 14 were reported as cured; 15 as improved; 1 died seren days after operation. In the fatal case the right common carotid artery was tied. No fit occurred after the operation.

In 10 cases of castration for epilepsy all were reported as cured. One case was reported four months after operation; 4 cases were reported more than two years after operntion; in 5 the time when reported is not mentioned.

In 9 cases of tracheotomy for epilepsy 2 were reported as cured; 6 as improred; 1 as much improved, though death in this case followed in two months after the operation.

In 24 cases of remoral of the superior cersical ganglia of the sympathetic nerres 6 remained well at the end of three years: 10 were improved; 5 remained unimproved; 2 died soon after the operation, but not from its direct effeet.

In 6 cases of incision of the scalp for epilepsy nothing was found to aecount for the symptoms. Three of these cases were reported as eured at the end of one year; 2 were reported as eured at the end of two years; 2 other cases, almost similar, were reported as eured.

Twelve cases of epilepsy are reported as curcd by sucb operations as stretehing of the scintic nerve, escision of the musculo-eutaneous nerve, eauterization of the larynx, circumcision, application of a seton to the back of the neck, 
tenotomy of the external recti muscles, hurning of the scalp, puncture of the beart, etc.

Thirteen cnses of spontaneous or accidental cures of epilepsy are also reported, at a time varying from two montbs to five years after the traumatism, which was a fall, n lurn, $n$ wound, nn amputation for intercurrent injury or discasc, etc.

Passing from the cerebral to the spinal region, Dr. White cites an illustrative case of his own. A man aged fifty-five years was attacked on Decemher 25, 1887, with severe pains in liig arms and shoulders. A few days later there was wealiness of the thighs, spreading rapidly down the legs to the feet, and upward on the body to the nipple line. In eight days there was ahsolute paralysis of the parts jnvolved, including both sphincters, while at the same time the paralyzed parts hecume the seat of profound annsthesia. Girdle pains developed, hedsores made their appearance, percussion of the spine over the third and fourtb vertehra became painful. The reflexes sicre exaggerated, and light blows on the hend in the direction of the spinal axis gave rise to frightful exacerhations of the girdle pains. In spite of every remedinl measure thesc symptoms increased in severity for ten months. In exploratory operntion was then nndertaken. Dr. White removed the apines and laminie of the first fire darsal rertebra, opened the slightly thickened dura, separated some firm adhesions to the subjacent pia mater, explored the cord, and having failed to discorer any serious pathological changes, closerl the wounds in the dura and soft parts.

The girdle pains had entirely disappeared hy the following day, sensation hegan to return in the feet the day nfter, voluntary motion in the toes after the eighth day, and so one symptom after another disappeared until the patient completely recovered, and is now earning his living hy manual lahor.

In the list of abdominal nnd pelvic disorders npparently cured hy operation per se a number of extraordinary cases are eited. The experience of Tait, who has more than once drawn attention to the astonighing disappearance of tumors, often of large size, after a mere exploratory incisiou, and the corrohorative testimony of Von Mosetig, are cited at length. Koenig's analysis of 131 cases of tuhercular peritonitis treated by ahdominal incision is carefully discussed.

In response to letters of inquiry upon the suhject, Dr. White received many communicatians from prominent operators, the great majority of tiem containing notes of cases not previously puhlished.

Among the signers of theec letters are to he found the names of Goodell, Hirst, Battey, Roswell Park, Lusk, Cheerer, Chas, T. Purles, Cahot, Hunter McGuire, Yancrede, Weir, Stimson, and many otbers of equal notc.

Under the heading of Xiscellaneous Operations the autbor has given several of ycry diverse character.

First are quoted cases of osteomalacia, cured, after wecks or months of confinernent in hed, hy either oüphorectomy or Casarcan section.

Passing to another suhject, the question of graduated tenotomy of the eye muscles for the rclief of gerere nervous symptoms is carefully discussed. The author freely acknowledges the value of tenotomies, both complete and graduated, in the restoration of equilibrium in hadly balnnced ocular muscles, hut he is none the less convinced that in numbers of instances of reported cures 
of chronic chorea, petit ma!, and even delusional insanity, the effect of the opcration per se is in large measure the potent cause of the supposed cure. This helief is founded not alone on thenry but upon the fict that in certain cases of rellex nerrous troubles a cesgatiou of the symptoms has followed the tenotomy, although this has not produced perfect equilibrium. Again, the relapses which znay take place after a perfectly succesiful series of tenotomies would indicate that the nervous phenomena attributed to the insufficiency, for the relief of which the operations were made, were not correctly so attrihuted, and that the temporary relief must he ascribed to some cause other than the restoration of an imperfect halance of the external ocular muscles.

In seebing for a reasonable explanation of the phcnomeua obsersed in the above eases, the author has formulated the conditions which are common to nearly all of them. These are:

1. Ansesthesia.

2. Psrchical influence, or so-called mental impression.

3. Relief of iension.

4. Reflex, action or the "reaction of traumatism."

These influences were operatice in the majority of cases, nlthough not one of them, except the last, applies to the whole list.

With the idea that it was conceivalle that a disense of the nerre centres not reached by ordinary drugs might he affected by agents of such volatility and difusihility as ether and ebloroform, the nuthor instituted a series of observations upun a number of epileptics in rarious stages of tho diseaso. All other treatment was withdrawn, ether $\$ 23$ given to the produetion of full anzithesia at intervals of from forty-eight to seventy-two hours. The results were either entircly negative, or in consequence of the withdrawal of their bromides the patients grew worse.

Since in the great majority of eases upon which Dr. White bases his paper there were either undoubted symptom;, such as are liabitually osyociated with organic disense, or there was demonstrahle and unmistakable cridence of such disease, it is necessary to believe, in eonsidering the psychical influence of operation, that poserful impressions acting upon the emotiounal or intellectual nature may affect the organic processes of secretion, nutrition, etc., and may arrest pathologieal elhanges and bring about reparative or recuiprative action. Cases are eited in which such infiucnces are clearly set forth.

The suthor holds that the normal equilihrium which we witness between the cerebro-spinal and the sympathetic systems as respects their influence upon the bloodressels is obriously more or less interfered with when the hrain transmits a more than wonted impulse, allowing the unrestrained action or paralyzing the influence of the sympathetic rosomotor nerre. In this relation the author narrates some remarkable cases of hypnotism, nnd quotes some striking examples of the influence of the central nervous system upon the hody.

Belief is expressed that in many of the cases descrihed there can be little douht that relief of tension is an important factor in amelioration or cure. If it is assumed that preternatural tension exists in the cranial cavity, this would be rclieved to an extent by trephining, and there would be hut ferr exceptions to the rule, that in each case snmething was done which lessened tension in 
the eavity or organ of the body. There are other cases, however, in which no such relief was ohtained, and yet curc resulted from operation. A diminution of the tension would manifestly alter the blood-supply to any important organ in the hody, and with it the nutritive processes, loeal and general. Beyond this nothing definite can be said except as it npplies to eases of aseites, in whieh, as in cases of hydrarth rosis, one tapping may prove permanently eurativc because the original souree of irritation and hypersecretion has alrendy disappeared.

Under the liead of Refex Action, the author ineludes the "reation of traumatism," as well as the cffects of revulsion and counter-irritation.

Verneuil has long since shown that very slight traumatism sometimes excites in the entire eeonomy a general perturhation, and sometimes, hy selection of the weak point, a sudden aggravation of lesions that are only slight or have slumbered. This sanc excitement, usually prejudicial, may occasionally be eurative. In the case of spinal surgery abore detailed, $\mathrm{Dr}$. White believes that the loeal shock of the operation tras promptly followed by a corresponding renction in which the vitality of the tissues was rajed sufticiently high to determine a return to the normal state. In this relation the reciproeal influenec of one portion of the body on another is briefly diseussed.

In considering ahdominal tumors, attcntion is called to the possibility of the spontaneous disappearance of such tumors, the relation of this disappenrance to the operation bcing coincidental; crses are eited in point. As to the cure or amelioration of growths thought to be malignant by merely exploratory operation, a long scarch through the literature of the subjcet has met with but littlc success.

The euro of tubereulosis of the pcritoneum as the result of exploratory incision is explained on the ground that the removal of ascitic fluid allows the peritoncal surfaces to fall together and to acquirc adhosions. The tubercles are then shut in betwcen the coils of intestine, the omentum, and the ahdominal wall. They arc thus surrounded by tissues in a high degree of activity, which can now throw around thein the limiting zone of young cells and erentually fibrous tissue, which, it the tuherculous grocess is not too far advaneed, may effectually resist it and may causc it to retrograde, the process heing analogous to that which wc see imperfectly going on around a cancerous growth.

As a result of a study of the seibject, the author helieves the followiug conclusions are warranted:

1. There nre large numbers of cases of different grades of severity and varying character whieh seem to be benefited hy operation alone, some of them hy almost any operation.

2. These cases inelude ehiefly epilepsy, certain ahdominal tumors, and peritoneal effusions and tuherele, thougl the improvement in the latter is, perlonps, to be explained on general principles.

3. Of the possihle factors whieh, hy reason of their constaney, must be eonsidered, nnxsthesia seems least likely to have been effectirc. The otber three-viz., psyehical influence, relief of tension, nnd reflex aetion-may enter in varying degrees into the thcrapeutics of these cases, and taken together, serve to render the oecurrence of occasional cures less mysterious. 
4. The theory of accident or eoincidence seareely explains the fucts satisfactorily.

\section{DeEr Urethral Medicatiox IN the Traamest of Ureturai Catakrh.}

Some practical suggestions for deep urethral mediention in the treatment of posterior urethral eatarrh are made hy lieres (lfellical Recort, vol.xi., No. 4), whose position as a genito-urinary surgeon is such as to entitle any of his writings to careful consideration.

He again calls attention to the fact that it is impossible tn say exactly what a stricture is, since every natural undulation of the canal may he so elassed ly the pligsicinn who is properly impreguated with the large-calihre-str.cture idea, and hence lie is sure to find what he looks for in erery case of gleet.

Keyes states that the rast majnrity of ehrnnie glcet cases have already been cut anteriorly in the urethra from nne to eleven times, and that very few of them have heen tested to ascertain whether thcy hare posterior urethritis or not. He states that one may easily learn how to cure many, and liagnosticate all, cases. Where the trnuhle is due to anterior urethral catarrh, cansed by stricture, granulations, or what not, the souree of the pus may he dcinonstrated without the endnscope hy gentle, thorough, hot irrigation of the anterior urethra by means of a soft eatheter passed into the sinus of the hulb, and the immediate subsequent use of the simple metallie bulhous hongie, provided the meatus be reasonahly large; for if the pus cones from granular or strictured portions of the pendulnus urethra, the jrrigation will only wash away what lies loose in the canal, and the hulh will subsequently bring fortb upon its shoulder soft muco-purulent clnts, generally tinged with hlood, which have heen scraped off the excoriated areas from around which the inflamed mucous membrane secretes whaterer free pus exists. There may be tight areas, which thc bulh will detect; but if there he not a granulating surface upon the tight area or behind it, which the bloody muco-purulent clots on the shoulder of the bulb will demonstrate, or their abscnce disprove, then the cutting of such tight archs will not favarahly modify gleet in most instances. Eren though there may be snme tight areas and a moderate condition of granulation, if there is also posterior urethritis the cutting of the tight areas, although it.mny greatly moderate, will not cure the glcet, and this should be told a paticnt hefore such operation is undertaken.

When there is posterior urethritis the quantity of pus lying in the urethri hehind the bulho-memhranous junction is disproportionately grent when eompared with the amount of gleety discharge that appears at the meatus. This niay he readily demonstrated. If the urcthra be milked by firm pressure with the finger, from the perincum forward, until all the pus tliat will come he squeezed nut, and then the patient he instrueted to urinate in tro parts, into separate glasses, if he have cren moderate posterior urethritis the quantity nf pus mixed with the firt urinary gugh, representing the washing out of the deep urethra, will be disproportionntely great when comparcd with what has flowed out spontaneously from the meatus or been milkcd out ly the physician before the urinary act, as shnwn by gross inspection nf the specimen. And if the grade nf posterior urethritis he intense, not only will the first 
urinary gush be purulent, but also the entire secondary fow will he turbid witb pus. In case of donbt, the nuterior urethra may be irrigated before the urinary test is applied. The pus may, of course, come from the prostate gland or the seminal vesicles; but this may be demonstrated by milking of these organs hy meanz of $\mathbf{n}$ finger in the rectum, between tbe first and second urinary flows, urine being retained in the blndder to be ejected in $n$ third urinary discharge, and the specimens to he exnmined microscopically after settling.

The clinical picture of posterior urethritis is fairly typical. Aftcr the subsidence of an acute attnck of gonorrhera, which hns, perbaps, heen complicated by cystitis or vesical irritability, there follows $n$ mild gleet. So long as the patient uses an injection, his uretbra remains dry and be thinks himself cured. On leaving off tbis trentment, bowever, the discharge reappenrs, sonetimes accompanied by discomfortiug sensations in the anterior urethra nenr the mentus, or referred to tbe perineum, and sometimes accompanied by urinary urgency and precipitancy. Wines, spirits, or indulgence in sexual intercourse promptly aggravinte the glect. Most of these cuses bare the anterior uretbra widely cut for a close stricture of large calibre, and are subscquently trented by large sounds, often witb much benelit; frequently, however, tbe passage of these instruments aggravates the discharge and ligbts up either cystitis, prostntitis, or epididymitis. 2Nost of these cases ultimstely get well, snd witbout local treatment.

Rest, halsams, slkalies, demulcent drinlis, counter-irritations, chsnge of air, treating of tbe anterior uretbra, irou in ch ronic cases, sll of tbese are potential, aud nost of tbese can bc bappily combined with locnl posterior trestment. Some fer cases are positively unsuited to local trentment and get worse under it. Most tubercular coses, and some simple inlinmmatory and some ordinary gonorrhceal eases, can be classed in tbis group. Wben the trentinent disagrees, symptoms become so promptly and obviously aggrnvated that the futility of repcating applications is at once clear. There is no danger of producing crstitis or epididymitis if instrumcuts nre used carefuliy nnd not inserted too fur; the rist incurred of occasioning these symptoms is rastly less than in tresting the disense with snterior injections or sounds and internal medication. The ivstrument employed is founded upon Ultzmann's model, differing from the latter in being mnde in one piece. The syringe bas only on minute opening at the tip. The latter may be inserted just within the hole in the triangular ligament, that is a tritlc beyond tbe bulho-membranous junction. The membranous turetbrn grasps the tip of the instrument, and the contents of the syringe, twenty minims, or more, may be gently tbrown in ; the entire injection will flow backwnd along the membranous uretbra, through the prostate, and into the blndder, with as little violence as possible, not oue drop escaping at the mentus upon the withdrawal of the syringe. Instead of using a few drops of stroug solution it is better to use a larger quantity of a mild solution. The entire contents of tbe syringe should be used in every instance, excepting when nitrale of silver is employed in a strength grenter than ten grains to tbe ounce. The strengtb of a given substance is increased gradunily after establisbing tolerance to milder strengths. When the source of the flow of pus is reasonably well forward in the urethrn 
the injection may he made before tbe paticnt urinates; when the infammition extends furtber hackward, and the supply of pus is considerahle, the patient should urinate just hefore making the injection, so that the fluid will flor into the bladder and become thoroughly applicd to the unucous membrane at the internal prostatic uretbral orifice, without being diluted or neutralized by coming in contact with urine in tbe bladder at this point.

In suitale cases the free pus disappents from the second urinnry fon, then it disappears entirely from the urine, sone sbreds still rcmaining. These are attacked by increasiug the strength of the injected fluid, or if there be some stricture in the membranous urethra by the use of sounds, after the catarrial surface lias been modified by the previous employment of injections, comhined often with antcrior astringent injections, wbich the patient himself administers.

After an extensive use of the various remedies which have the reputc of controlling the flow of pus from mucous mcmhranes, Keyes relics almost exclusively upon four substances-sulphate of thallin, sulphate of copper, glycerole of tannin, and nitrate of silver.

The sulphate of thallin is hland and practically unirritating, and may be uscd up to a saturated solution, which is about twenty-four per cent. It is suitable in all the acuter forms of inflammation (except cases of acute frank, recent gonorrbonl cystitis, in which the nitrate of silver bus the preference), and is the substance which should first he used in a watery solution of about three per cent., increasing at each injection up to six, nine, and even twejve jer cent. The list-named strength will usually accomplisb all tbat this drug can do in reducing the free secretion of pus. The intervals between injection should be two, three, or four days, according to the effect. The treatment causes practically no discomfort, and the injection may he retained as long as the patient chooses.

The sulphate of copper is used in the strength of onc per cent. in pure glycerin. This solution is given in water, commencing with about one grain to the ounce and working up rapidly to full strength. This drug is markedly astringent in suitable cases.

Wbere a more astringent effect is aimed at than tbat produced hy copper, the glycero-tannin may he employed. "Thia substanee is too tbick to he sucked readily into a syringe. It is thinned hy the addition of watcr.

Nitrate of silver is exceediogly raluahle in gonorrhcal cystitis, and is most useful when copper and tannin prore inefficient. The first injection should be of the strengtin of about onc grain to the ounce. The applications are made from toree to eight day's apart, and are increased in strength to ten grains to the ounce. This is tbe harshest of the applications, but carefully used is free from danger of producing complication, and is rery efficient. Thallin and nitrate of silver sbould not he used in the same syringe, as a black. solution is made which is dificult to wash out. 